\title{
DISTRIBUTION OF WITHIN-RING INTERNAL CHECKING IN Pinus Radiata GROWN IN SOUTHERN CHILE
}

\author{
DISTRIBUCIÓN DE GRIETAS INTERNAS INTER-ANULARES EN \\ Pinus Radiata CRECIDO EN EL SUR DE CHILE
}

\section{A. Aguilera ${ }^{1}$, L. Inzunza ${ }^{1}$}

\begin{abstract}
The increase of Pinus radiata plantations in Chile has brought larger annual volumes to the industry and the opportunity to process them into value-added products. Within-ring checks constitute an important problem that may affect the appearance quality of lumber. This problem occurs in the early wood portion of sapwood growth rings in dry lumber and can only be seen when the board is cross cut.

The purpose of this study was to analyze the frequency of within-ring internal checking in kilndried Pinus radiata lumber from different logs grown in southern Chile. Centre boards were more affected by the internal checking. Checks were located more frequently between rings 4 to 6 .
\end{abstract}

Key words: Internal checking, radiata pine, sawmill, kiln-dried.

\section{RESUMEN}

El incremento de las plantaciones de Pinus radiata en Chile ha entregado importantes volúmenes a la industria y por lo tanto la oportunidad de transformarlos en productos de alto valor. Las grietas internas constituyen un problema que puede afectar la calidad de la madera, en particular en aquellos productos que se clasifican por su apariencia. Este problema se puede apreciar en la zona de madera temprana de la albura en madera seca y sólo cuando la madera es trozada.

El propósito de este estudio fue el de analizar, la frecuencia de aparición de grietas internas interanulares en madera seca de Pinus radiata. Como resultados, se encontró en las tablas centrales, compuestas por madera juvenil, una alta frecuencia de grietas internas entre los anillos 4 y 6 .

Palabras clave: Grietas internas, pino radiata, aserrío, madera seca. 


\section{INTRODUCTION}

Within-ring checking is one type of internal checking, where the checks are internal to the wood, and generally do not break the surface or become visible without processing, as distinct from surface checking (Miller and Simpson 1992a, Booker 1994).

Within-ring internal checking appears with higher frequency in fast growth conifers species such as Pinus radiata (Cown and McConchie 2000, Ball et al. 2001). It is after the kiln drying process that these checks become visible. Depending on the severity of the defect, it can cause rejects, raw material losses and increased processing costs.

Cown and McConchie (2000), Simpson et al. (2002), Ball et al. (2005a, b) note that some factors that determine the appearance of within-ring internal checking are the site, genetic factors, the board position on the log and kiln-drying intensity. According to Miller and Simpson (1992), within-ring checks are formed during the kiln drying process and are thought to be a consequence of the early wood collapse, often resulting in several checks inside a growth ring. The authors indicate that little can be done to prevent within-ring checking by, for instance, reducing the thickness of the board or the drying temperature.

Vera et al. (2007) indicated in a study of radiata pine drying that the percentage of internal checking found in this species is especially variable.

Miller and Simpson (1992b) state that there is a great variability in the occurrence of checks, because some trees show many checks whereas others do not show any trend. In particular, most of the internal checks in radiata pine were found between the growth rings 9 to 15 . This growth region corresponded to the wood produced following the first thinning (9 years). Miller and Simpson (1992a) and McConchie (1999) add that within-ring internal checking is more frequent in central wood between the rings 5 to 15 from the pith.

Simpson et al. (2002) indicate some factors that influence within-ring internal checking in radiata pine: between the non-processing/resource parameters is the earlywood ring width (growth rate) which would be more likely to develop internal checks. With regard to heartwood, the author said that in radiata pine heartwoods boards do not develop internal checking and collapse because their moisture content is too low. They also add that sapwood boards cut from the inner sapwood are more prone to collapse and develop internal checking than boards from the outer sapwood, concluding to this may be due to thinner cell walls, greater annual ring curvature, or greater thickness of the earlywood.

With regard to the distance from the butt, Simpson et al. (2002) specify that the tendency to form within-ring internal checks decreases with the tree height, being the bottom of the butt log the most affected.

Being internal checking a problem in Chilean radiata pine, mainly at the millwork industry, the following questions arise: how affected will the boards be? Which boards are more affected? And hence depending of the ring position, estimation of whether it is a sawmill problem. Therefore, the purpose of this study was to analyze, in a common sawing pattern for Chilean radiata pine, the frequency in radial distribution by log length of the internal checking in kiln dried, pruned radiata pine lumber grown in southern Chile. 


\section{METHODOLOGY}

The raw material came from a 23 year old radiata pine stand and consisted of 15 pruned logs ( 5 meters long), grown in the southern region of Chile, near the city of Valdivia $\left(39^{\circ} 38^{\prime} \mathrm{S}, 73^{\circ} 5^{\prime} \mathrm{W}\right)$. The trees were selected from the mean quadratic diameter of the stand, corresponding to diameter class 30 $32 \mathrm{~cm}$. The final crop stocking was about 440 trees/ha, and the time elapsed between falling, sawing and drying, was about 20 days.

The selected logs were sawn to produce 4 lateral pieces of 39 X $203 \mathrm{~mm}$ and three central boards of 51 X $203 \mathrm{~mm}$ (figure 1). All the resulting material (60 lateral boards and 45 centrals boards) were processed full length ( 5 meters long boards), and then the lateral boards separated from the centrals ones to be processed each at a $100 \mathrm{~m}^{3}$ commercial kiln, with schedules dedicated for lateral or central lumber, for 80 to 100 hours, to reach up to 8 to $12 \%$ of moisture content. Following the kiln drying process, the logs were rebuilt to determine the position of every piece.

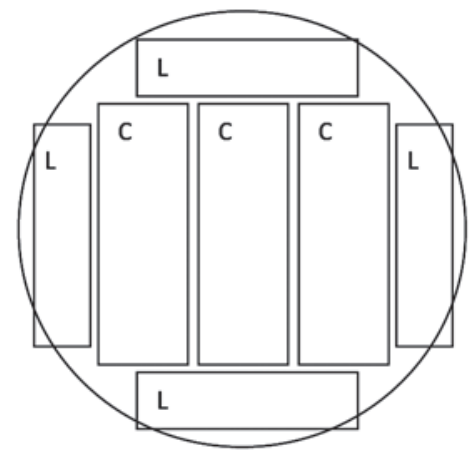

Figure 1. Identification scheme for lateral (L) and central boards (C).

After the log reconstruction, all boards were cross-cut every $10 \mathrm{~cm}$ from the base end, in order to find and count the internal checks. In every section the number of checks and checking ring position were recorded.

Basic density and moisture content was measured on half-disc cuts at stump height. Samples were weighed, oven-dried, reweighed and their moisture content calculated. In order to determine the basic density of the boards, a sub-sample of $2.5 \mathrm{~cm}$ thick was cross-cut each $50 \mathrm{~cm}$, the volume was measured by displacement and then the sample was dried to constant weight at $103^{\circ} \mathrm{C}$. This procedure was applied in both types of boards considering that the central lumber concentrates the portion of juvenile wood. 


\section{RESULTS}

The following table shows the data dispersion for wood basic density and moisture content on discs cut at stump height and also for the samples extracted from central wood every $50 \mathrm{~cm}$ along each board.

Table 1. Wood basic density and moisture content on discs and density for central boards

\begin{tabular}{|c|c|c|c|}
\hline & $\begin{array}{c}\text { Basic density on } \\
\text { discs }\left(\mathrm{kg} / \mathrm{m}^{3}\right)\end{array}$ & $\begin{array}{c}\text { Moisture } \\
\text { content }(\%)\end{array}$ & $\begin{array}{c}\text { Basic density in } \\
\text { central boards } \\
\left(\mathrm{kg} / \mathrm{m}^{3}\right)\end{array}$ \\
\hline Min & 364 & 113 & 319 \\
\hline Mean & 404 & 150 & 364 \\
\hline Max & 436 & 180 & 447 \\
\hline St Dev & 21 & 16 & 30 \\
\hline
\end{tabular}

The summation of internal checking for all sampled logs is shown in figure 2. It is possible to distinguish a high check frequency in the first 2 meters from the base of the log, with a peak frequency at about 1.3 meters, $3.0 \mathrm{~m}$ and $4.5 \mathrm{~m}$. i.e. internal checking was found at every position in the log length, from 0 to five meters long. It is also interesting to note that at lower positions in the log, fewer checks were found. Note that every board was initially of 5 meters long, then cross cut to detect the internal checking presence.

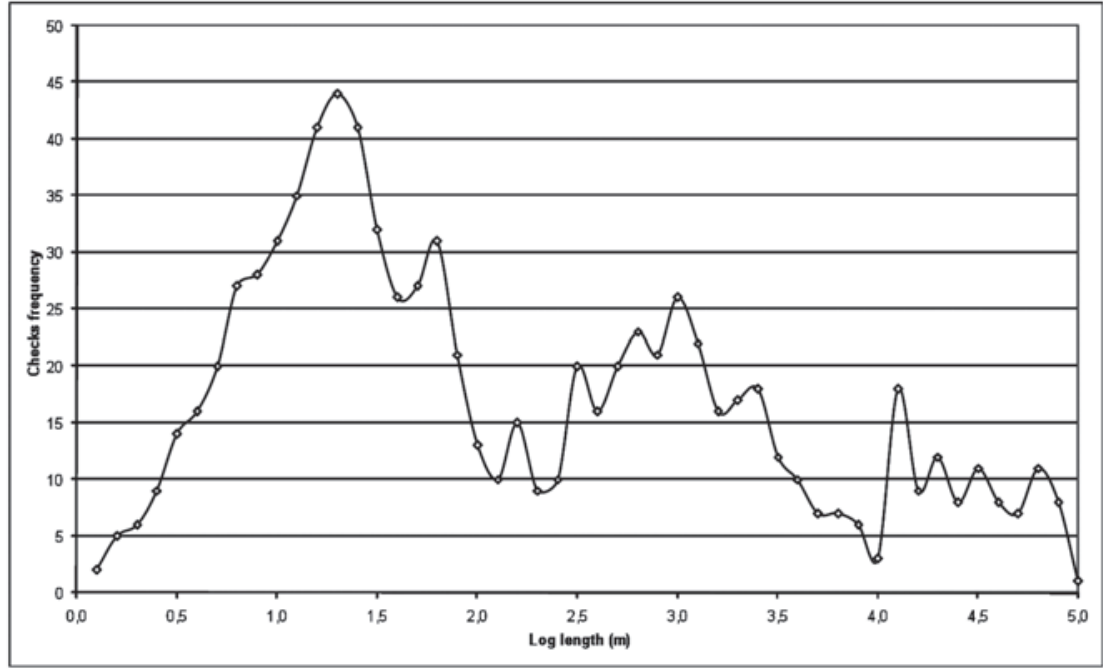

Figure 2. Frequency distribution of internal checking by log length

Also, out of the 15 pruned logs studied, two logs showed no presence of internal checking, $6 \operatorname{logs}$ had a lower presence (less than 17 checks total) and seven logs had a high checking frequency. Even at low level, checking were located at about 1.5 to 2.0 meters of log length, while in the highly checked $\operatorname{logs}$, two of them were compromised on their full length but, in general, with a decreasing frequency in the tree height. These logs clearly indicated the three peaks of frequency; with declining internal chec- 
king between the peaks. This may be due to the presence of knots in those areas; moreover, we infer that the earlywood density of the rings around and close to the branches is slightly higher than between the whorls of branches, causing the less checking frequency detected.

Figure 3 shows the frequency distribution of internal checking by ring position. It is possible to segregate the presence of this defect at three levels of cross section: from ring number 1 to 3 , from ring 4 to 6 and from ring 7 to 9 , being the section from ring 1 to 9 in radiata pine composed mainly by central boards of low density, as described in figure 1, with juvenile wood. Kretschmann (1998) and Larson et al. (2001) indicate that in its first years of growth, a tree produces juvenile wood; a zone of wood extending outward from the pith. In conifers, and compared with mature wood, it has a lower specific gravity, thinner cell walls and occasionally disproportionate amounts of compression wood.

The internal checks found in rings section 4-6, present a higher frequency than others sections. It is also in section 1-3 at about 1.5 meters log length where the checks appear to reach another peak of frequency, decreasing strongly over 2.5 meters length. For rings section 7-9 few checks were observed over the entire log length position.

In figure 3, and according to the sawing scheme indicated in figure 1, the most affected boards were located in central positions mainly at 1.5 meters, which included the pith and a high proportion of juvenile wood. To a lesser extent, some checks were found in lateral boards at low levels in the log.

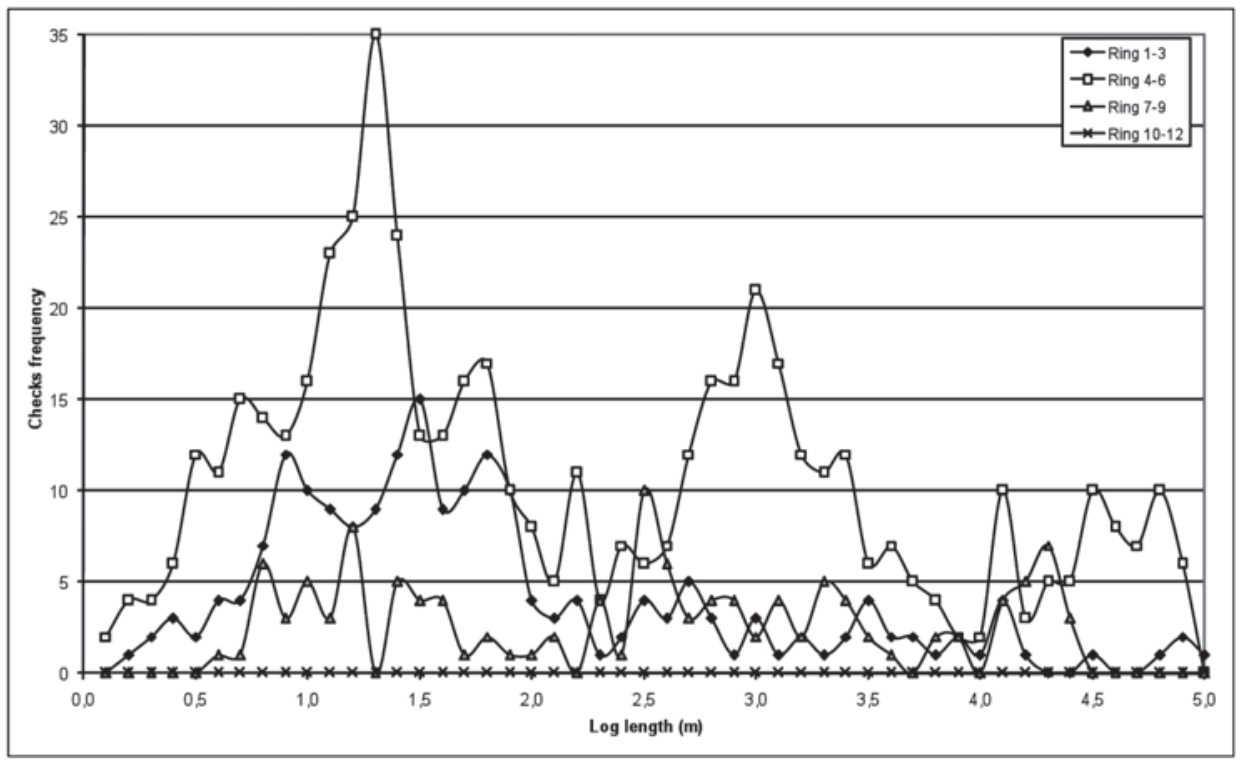

Figure 3. Accumulative frequency distribution of internal checking by ring position

Across the radius, internal checking was distributed as shown in figures 4 to 6 . Most of the internal checking was observed in the central boards with greater frequency between growth rings number 4 and 6 . In these 23-year-old Chilean Pinus radiata, the boundary ring number between heartwood and sapwood was between the rings numbers 2 to 5 . Checking was rarely present in the heartwood portion. 


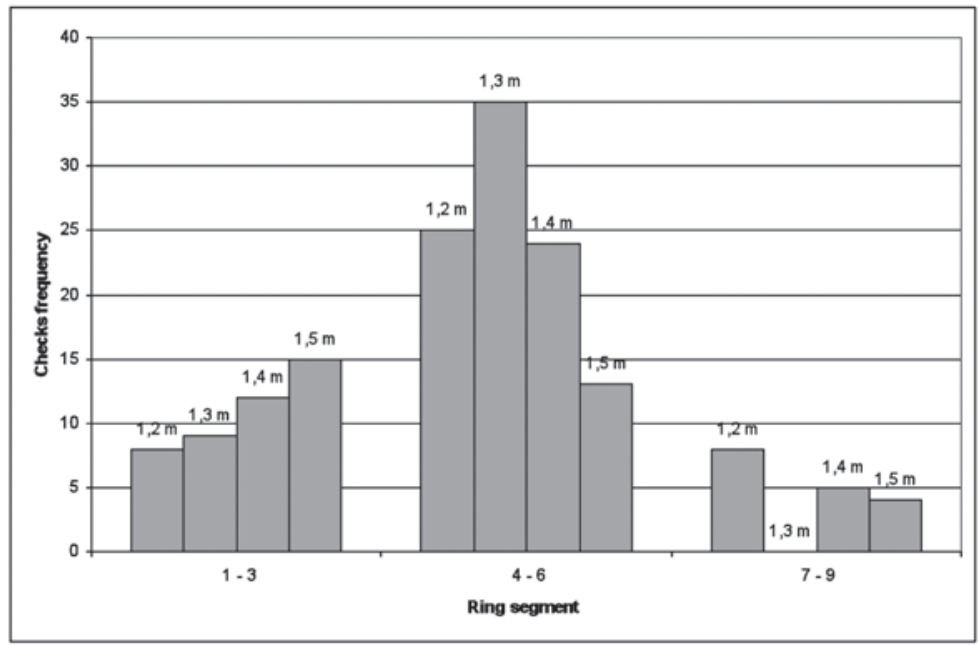

Figure 4. Radial distribution of internal checking from $1.2 \mathrm{~m}$ to $1.5 \mathrm{~m} \log$ length

In figure 4 the check distribution in cross section is presented by the low portion of the log. Checking was greater between growth rings 4 to 6 . It is possible to observe the same behaviour in figures 5 and 6 , which correspond to the middle and top section of the log.

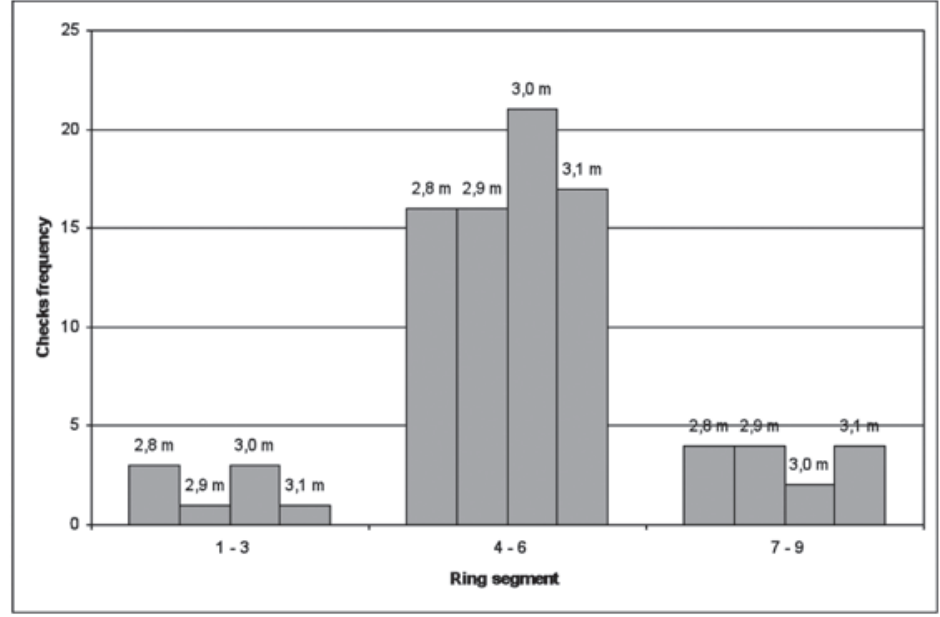

Figure 5. Radial distribution of internal checking from $2.8 \mathrm{~m}$ to $3.1 \mathrm{~m}$ log length

It is in low density boards that internal checking are observed (between ring segment 1 to 9), corresponding for the sawing pattern with central boards. No checks were found over ring 9 . As tree height increased, fewer checks were found but the existing ones were located mostly between rings 4-6 (figure 6). The most affected boards were the central ones but checks were also present in lateral boards at middle and top heights, possibly caused by log curvature. 


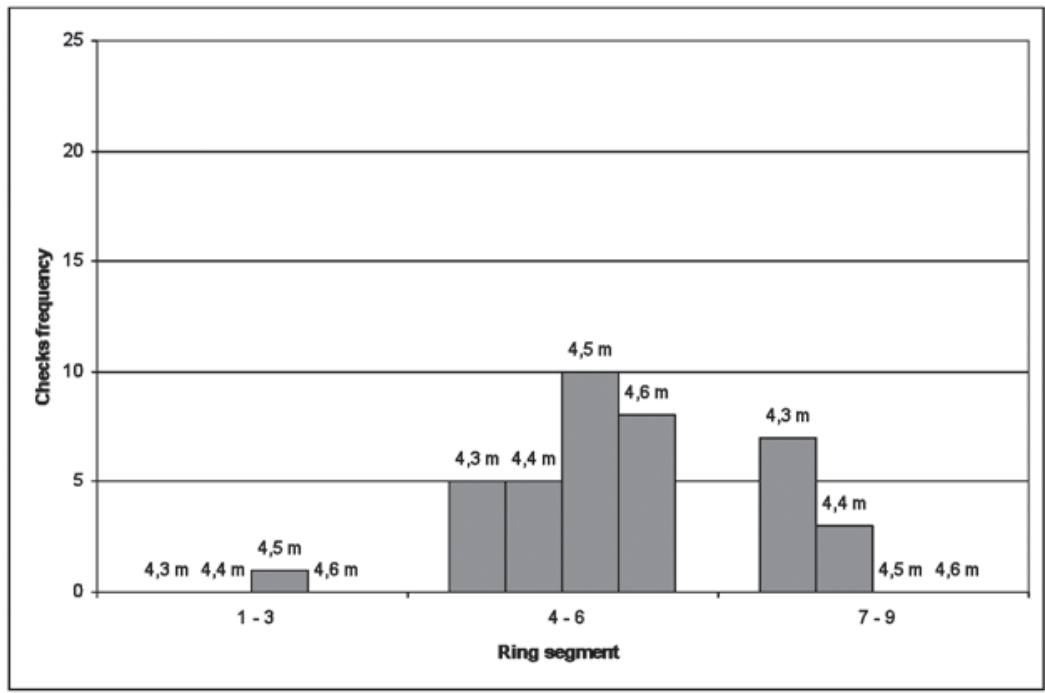

Figure 6. Radial distribution of internal checking from $4.3 \mathrm{~m}$ to $4.6 \mathrm{~m}$ log length

Internal checking frequency by log length and its relationship with wood density of central boards is shown in figure 7. A continuous decrease of wood density with an increasing tree height (log length) was observed, starting with about $393 \mathrm{~kg} / \mathrm{m}^{3}$ at the $\log$ base, to reach about $350 \mathrm{~kg} / \mathrm{m}^{3}$ at the $\log$ end.

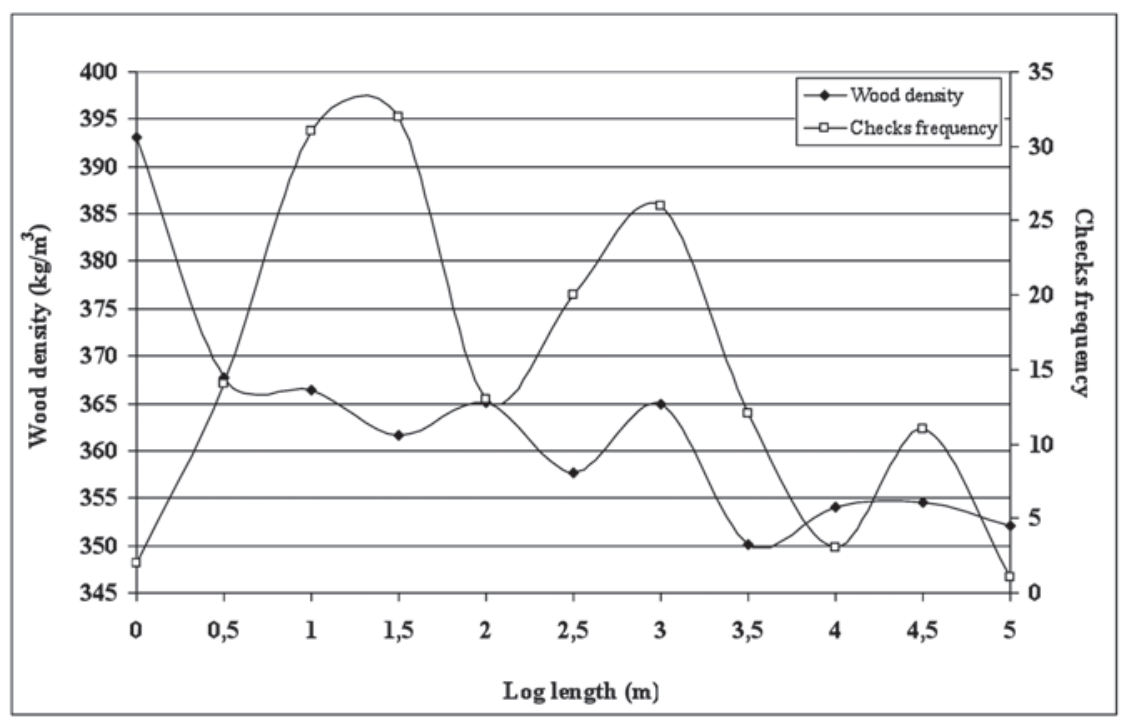

Figure 7. Relationship between wood density and internal checking frequency

However, there was no evidence that the wood density has a positive effect on internal checking, but intra-ring density variation it's probably an interesting variable that may explain checking mainly on the earlywood portion of the ring, considering some important features on the cellular growth and development characteristics as tracheid length, diameter but also the wall thickness as a subject to continue further research. 
The results are consequent to the findings of Simpson et al. (2002), where internal checking was observed with greater intensity at the bottom of the butt log. According to the radial distribution, the checks are turning away from the pith, being largely concentrated among the rings 4-6. This may indicate that for example, $30-32 \mathrm{~cm}$ average diameter logs, with a relatively low curvature, are probably less susceptible to internal checking on laterals boards, however if the average log diameter decreases, and/or if the curvature increases, the checks will appear in these boards, a millwork raw material that do not accept this defect.

These results are preliminary and the data limited by its sample size, therefore, the number of studied logs should increase in order to establish lines of accurate trend, which would show more clearly the severity of this defect.

The literature reports many variables like earlywood width, cell wall thickness, ratio of latewood to earlywood width, moisture content and distance from the pith, that predispose the wood material to develop internal checking, however, the drying process remains as the main problem that act trigging the beginning of the checks.

Finally, factors such as growth rate on radiata pine and its impact on the reduction of the wood density, particularly sensitive in earlywood, are variables to consider on checking intensity at the cross section and through tree height.

\section{CONCLUSIONS}

Three log sections showed a higher frequency of internal checking, at 1.3,3.0 and 4.5 meters of log length but with a critical section at $1.3 \mathrm{~m}$, where more internal checks were found. The declining presence of internal checking between peaks may be due to the knots in the surrounding area; we infer that the earlywood density of the rings close to the branches is higher than between the whorls of branches, causing the lower checking frequency detected.

In cross section, internal checking was concentrated between rings number 4 to 6 , which also correspond to central boards with juvenile wood. Outside this ring section, the number of checking decreased along the boards, disappearing in rings 1-3. Therefore, it is possible to find internal checking at every board position in length, but with more intensity in juvenile wood.

With regard to wood basic density of the affected boards, there is not clear evidence towards finding internal checking in low density boards, however, intra-ring density variation is an interesting variable in need of further research, which might explain the checking on the earlywood portion of the ring, considering some important features on the cellular growth and development characteristics such as tracheid length, diameter and also wall thickness.

In the sawing pattern, internal checking was distributed between the three central boards, with a minor participation of lateral boards, some of which never showed checks. When outer boards were affected by checks, it was probably due by the curvature of logs resulting in low density wood in these boards.

\section{ACKNOWLEDGMENTS}

We appreciate the cooperation and support of the Research and Development Direction (DID) of the Universidad Austral de Chile. 


\section{REFERENCES}

Ball, R.D.; McConchie, M.; Cown, D.J. 2005a. Intra-ring checking in a study of 29 clonesevidence for associations with SilviScan variables. Fifth Workshop IUFRO S5.01.04, Waiheke Island, Auckland, New Zealand. 9pp.

Ball, R.D.; McConchie, M.; Cown, D.J. 2005b. Evidence for associations between SilviScanmeasured wood properties and intraring checking in a study of twenty-nine 6-year-old Pinus radiata. Can. J. For. Res. 35:1156-1172.

Ball, R.D.; McConchie, M.; Cown, D.J. 2001. Heritability of internal checking in Pinus radiataevidence and preliminary estimates. New Zealand Journal of Forestry Science 31(1): 78-87.

Booker, R. 1994. Internal checking of radiata pine occurs at the start of drying. Wood drying. Issue $\mathrm{N}^{\circ} 16$.

Cown, D.; McConchie, D. 2000. Internal checking. Wood processing newsletter, Forest Research, Issue $\mathrm{N}^{\circ} 27$.

Kretschmann, D. 1998. Properties of juvenile Wood. TECHLINE, Properties and use of wood, composites, and fiber products. United States Department of Agriculture, Forest Service, Forest Products Laboratory. VI-7 Issued 09/98.

Larson, P.; Kretschmann, D.; Clark, A.; Isebrands, J. 2001. Formation and properties of juvenile wood in Southern pines. A synopsis. United States Department of Agriculture, Forest Service, Forest Products Laboratory, General Technical Report FPL-GTR-129

McConchie, D.L.1999. An update on within-ring internal checking including a procedure to identify logs prone to form check during drying. Proceedings of 3rd Wood Quality Symposium. Emerging Technologies for Evaluating Wood Quality for Wood Processing. New Zealand Forest Research Institute, Rotorua.

Miller, W.; Simpson, I. 1992a. Categorizing internal checking in radiata pine. Wood drying. Issue $\mathrm{N}^{\mathrm{o}} 13$.

Miller, W.; Simpson, I. 1992b. Collapse associated internal checking in radiata pine. 3rd IUFRO Drying Conference, Vienna, Austria. pp 298-308.

Simpson, I.; Booker, R.; Haslett, T. 2002. Within-ring internal checking. Wood Processing Newsletter, Forest Research, Issue No. 32.

Vera, J.; Ananias, R.; Diaz, J. 2007. Some factors affecting the within-ring internal checking during drying of radiate pine. Maderas. Ciencia y tecnolología 9(2):145-159. 
